\title{
Bibliography of Charles Harvey Brown
}

1905 "Bibliographical Society of America: Chicago Chapter." Library Journal 30:15455, March 1905. Minutes of Council meeting, Charles H. Brown, secretary.

1906 List of Titles on Municipal Government, with Special Reference to City Charters and to Local Conditions in Chicago. Prepared at the request of the City Club of Chicago for the Chicago Charter Convention. Chicago, City Club, 1906. (Publication, No. 3) 51p.

1907 "Public Documents in Technical Libraries." Papers and Proceedings of the Twenty-Ninth Annual Meeting of the American Library Association Held at Asheville, N.C., May 23-29, 1907. (Bulletin of the American Library Association $1: 156-57$, July 1907.)

"Use of Scientific and Technical Books." Ibid., p. 163-65.

IOII "Limitations of the Branch Librarian's Initiative." Papers and Proceedings of the Thirty-Third Annual Meeting of the American Library Association Held at Pasadena, Calif., May I8-24, I9II. (Bulletin of the American Library Association 5:105-09, July 19II.) Also appeared in Library Journal $36: 333-36$, July i 911 .

I9I6 "The Libraries and the Stevens Bill." Public Libraries 21:126, March 1916.

I9I9 "Naval Libraries-Present and Future." Library Journal 44:235-4I, April 1919.

I920 "Naval Libraries." Library Journal 45:169-70, Feb. -15, 1920.

1923 "Books-Why Not?" Iowa Homemaker 3:3, 18, December 1923 .

"The' Relation of Agricultural Library Extension to the Work of the Public Library Commission." Bulletin of the American Library Association $17: 216$, July 1923.

1924 "University Extension Library Service in Relation to Other State-Wide Library Agencies." Bulletin of the American Library Association 18:352-53, August 1924.

1925 "The Iowa State College Library." Library Journal 50:532-34, June 15, 1925.
1926 "Some Objectives for Agricultural Libraries." Agricultural Library Notes I:I2226, September-October 1926. Also appeared in Bulletin of the American Library Association 20:474-76, September 1926; Library Journal 51:1001-04, Nov. 15, 1926.

1927 Discords; A Playlet on the Science of Reading, for Parent Teachers' Associations, Women's Clubs and High School Assemblies. Ames, Iowa State College Library, 1927. (Mimeographed.)

"Fundamentals in Reading: Reflections." Libraries 32:163-66, April 1927.

"Opportunities for Iowa Librarians." Iowa Library Commission Quarterly 10:13133, January-March 1927.

"Opportunities of Agricultural Colleges for Library Extension." Agricultural Library Notes 2:83-85, May-July 1927. Abstracted in Bulletin of the American Library Association 27:327-28, October 1927; and Libraries $32: 420-21$, October 1927.

"Outline Course with Problems on the Use of the College or University Library." School Library Yearbook I:99-122, 1927.

"Radio Broadcasting by Libraries." $\mathrm{Li}$ brary Journal 52:922, Sept. 15, 1927.

1928 "The Library on the Air." Library Occurrent 8:238-40, July-September 1928. Abstracted in Bulletin of the American Library Association $22: 453-54$, September 1928; and New York Libraries I1:115, August 1928.

"Library Radio Broadcasting. II. Mr. Brown's Reply." Library Journal 53:358, Apr. 15, 1928.

"Publicity over the Radio." Publishers' Weekly II4:234-35, July 21, 1928.

"Radio Broadcasting Round Table." Library Journal 53:619, July 1928.

"Some Fundamentals of College and University Library Buildings." By Charles $\mathrm{H}$. Brown and Frances Warner. Library Journal 53:85-87, Jan. 15, 1928 .

1929 Budgets, Classification and Compensation Plans for University and College Li- 
braries; Report of the Committee on Classification of Library Personnel of the American Library Association, December 1928. Chicago, American Library Association, 1929. Prepared by a subcommittee under chairmanship of Charles $\mathrm{H}$. Brown.

"Librarians as Stockholders." Library Journal 54:39, Jan. I, I929.

"Librarianship in Iowa." Iowa Library Quarterly II :49-50, October-December 1929.

"Review of Group Meetings of University, College and Reference Librarians." College and Reference Library Yearbook I : 13-22, I929.

"What Two Dollars Will Do!" Library Jouirnal 54:672, August 1929.

1930 "Bridging Deep Rivers." Wisconsin Library Bulletin 26:234-39, October 1930.

"Review of Group Meetings of University, College and Reference Librarians." College and Reference Library Yearbook 2:II-20, I930.

"The Library." In Survey of Land-grant Colleges and Universities (Bulletin of the U.S. Office of Education 9:609-714, 1930). Washington, Government Printing Office, I930.

1931 "Alumni Education and Its Relation to the Library of the Changing College." Bulletin of the American Library Association $25: 23-3$ I, January I93I.

"A Hazard to Research." Journal of Higher Education 2:420-26, November 1931. Also appeared in Library Journal 57:261-65, Mar. I5, I932.

1932 "College Libraries in the Depression."

By Charles H. Brown and Frances Warner. Bulletin of the American Library Association 26:74-78, February 1932.

"The College Library by W. M. Randall." Library Journal $57: 624-25$, July 1932.

"Inter-library Loans: an Unsolved Problem." Library Journal 57:887-89, Nov. I, I932.

"Is the Librarian a Victim or a Beneficiary of the Land-grant Survey?" Bulletin of the American Library Association 26:43 I-35, July I932.

"Reading vs. Reviewing: an Experiment in Broadcasting." Publishers' Weekly 122:49597, Aug. 13, 1932.

"Spirit of the Land-grant Library." Agricultural Library Notes 7:29-30, March-April I 932.

1933 "Bringing the Periodical Situation Up to Date." Bulletin of the American Library Association 27:379-80, September 1933.

Circulation Work in College and University Libraries. By Charles Harvey Brown and Humphrey G. Bousfield. Chicago, American Library Association, 1933. I79p.

"Discussion on German Periodicals." Library Journal 58:978-85, Dec. I, I933.

"German Periodicals in American Libraries: Deflation or Extinction?" Library Journal 58:525-28, June 15, 1933.

- A Summary of Reports of Iowa State College Library, July I, I923-June 30, I933 with an Outline of Possible Lines of Development, 1933-1953. Ames, Iowa State College, 1933. 26p. (Iowa State College, Official Publication, v. 32 , no. 4)

I934 "Analytical Study of the Use of a College Library." By H. V. Gaskill, Ralph M. Dunbar, and Charles H. Brown. Library Quarterly 4:564-87, October I934.

"College Library Budgets and the Increased Cost of Book Purchases." School and Society 40:224-26, Aug. 18, 1934.

"College Library Standards by Blanche P. McCrum." Library Journal 59:519, June I5, I934.

"German Periodicals and American Libraries." Science (new series) 79:250-52, Mar. 16, I934.

"Library Budgets and the Cost of Periodicals." Library Journal 59:637-38, Sept. I, 1934. Also appeared (slightly abridged) in Bulletin of the American Library Association 28:594-95, September I934.

"Planning the Future of Iowa Libraries." Iowa Library Quarterly 12:101-02, JulySeptember 1934 .

"Report of the Second Activities Committee." By Paul North Rice, chairman, Charles H. Brown, and Mabel Louise Conat. Bulletin of the American Library Association 28:859-72, December 1934 .

"Some Observations on the Cost of Periodicals." Bulletin of the American Library Association 28:647-49, September 1934 .

"Supplementary Notes on German Periodicals." Library Journal 59:62-63, Jan. I5, I934.

"Use of Bibliographies by Workers in the Agricultural Field." Bulletin of the American Library Association 28:547-48, September 1934 .

1935 "Adequate Library Support; How Can It Be Secured?" Bulletin of the Ameri- 
can Library Association 29:455-61, August 1935.

"German Periodicals Again." Science (new series) 82:38, July 12, 1935. Also appeared in Library Journal 60:619, August 1935.

"German Periodicals-Further Addenda." Library Journal 60:752-53, Oct. I, 1935.

"Government of the American Public Library by C. B. Joeckel." Bulletin of the American Library Association 29:498-500, August 1935.

Library Service in Iowa, Prepared by C. H. Brown.... A Report Submitted to the Iowa State Planning Board by the Committee on Public Education. Project 1043. [Ames, Iowa, State Planning Board, 1935.] 55 numb. leaves. (Mimeographed.)

"The Recent Concession on German Books and Periodicals." Library Journal 60:607, August 1935.

Les Tendences Economiques dans les Bibliothèques Americaines et Leur Influence Probable sur la Publication de Matières Scientifiques. [Ames, Iowa, 1935.] 6 leaves. (Mimeographed.) Summary of a report presented to the Comité International des Bibliothèques, Madrid, May 30, 1935.

Twenty-year Development Program, Iowa State College Library, Presented June I, 1935. Reprinted from the Twenty-Year Development Program, Iowa State College, Part I,p. 87-92. Ames, Iowa State College Library, 1935. I5 numb. leaves. (Mimeographed.)

1936 "Circulation Work in College and University Libraries." Chinese translation by Huang Yuan-tu, Wen-hua chi-k'an 8:265-74, June $1936 ; 420-28$, September 1936.

"Financial Reports, Unit Costs and Terminology." Library Journal 61 :190, Mar. I, 1936. Review of Financial Reports for $\mathrm{Col}$ leges and Universities by the National Committee on Standard Reports for Institutions of Higher Education.

"Iowa State College Library." Agricultural Library Notes i I :47-50, January. 1936.

"Statistical Data and Their Use in the College Library." Bulletin of the American Library Association 30:225-28, April 1936, Pt. I.

1937 "Extension of Service Charges." Library Journal" 62:794, Nov. I, 1937.

"The New Service Charges for Biological Abstracts." Bulletin of the American Library Association 31:971-72, December 1937.
"Reorganization of the College and Reference Section." Bulletin of the American Library Association 31 :589-601, September 1937. Charles H. Brown, chairman.

"Rural Library Extension." Bulletin of the American Library Association 31:706-10, Oct. 15, 1937.

"Sectional Reorganization." Bulletin of the American Library Association 31 : 193-97, April 1937.

"Some Similarities and Differences in the Administration of University Libraries in the United States and Germany." In Festchrift Georg Leyh. Leipzig, O. Harrassowitz, 1937, p. 329-42.

1938 "A.L.A. Reorganization." Bulletin of the American Library Association 32:1055, December 1938. Also appeared in Library Journal 63:924, Dec. I, 1938.

"Abstracting and Indexing Journals Discussed." Bulletin of the American Library Association 32:81-82, February 1938 .

"Advice to a Young Library." School and Society 48:401-02, Sept. 24, 1938.

"Aims of the Third Activities Committee." Bulletin of the American Library Association $32: 679-8$ o, Oct. I, 1938.

"Annual Report [of the Committee on A.L.A. Activities] 1938-1939." Bulletin of the American Library Association 32:610, September 1938; $33: 600$, September 1939.

"Forum Discusses A.L.A. Reorganization." Bulletin of the American Library Association 32:489-96, 526, August 1938. Charles H. Brown, forum chairman.

"The Reorganization of the A.L.A." Bulletin of the American Library Association $32: 674-79$, Oct. 1, 1938. Introduction by Charles H. Brown.

"Reorganization of the American Library Association." Abstract, P.N.L.A. Quarterly $3: 26-29$, October 1938.

"Report of the Committee on Reorganization [of the College and Reference Section]." Bulletin of the American Library Association $32: 8$ Io-I I, Oct. 15, 1938.

"What Shall We Do with the A.L.A.?" Bulletin of the American Library Association $32: 29-31$, January 1938.

"Your Views Invited." Library Journal 63:568, August 1938.

1939 "College and University Library Service edited by A. F. Kuhlman." Journal of Higher Education 10:346-47, June 1939.

"Equal Library Opportunities for All 
Iowa." Iowa Library Quarterly 13:130-34, January-March 1939.

"Final Report of the Third Activities Committee." A.L.A. Bulletin 33:782-804, December 1939. Charles H. Brown, chairman.

"International Directory." Library Journal 64:791, Oct. 15, 1939. Review of International Directory of Agricultural Libraries by the International Institute of Agriculture.

"New Library Building at Goucher Colege." Library Journal 64:276, Apr. I, 1939.

"A.L.A. Activities Committee." A.L.A. Bulletin 33:P-64, Oct. 15, 1939 [Proceedings].

"Tentative Report [of the Third Activities Committee]." A.L.A. Bulletin 33:359-453, June 1939. Excerpt in Modern Librarian 9:155-73, July-September 1939, Charles H. Brown, chairman of the committee.

"To All A.L.A. Members." Library Journal 64:522, July 1939 .

1940 Portrait. A.L.A. Bulletin $34: 72$, February 1940.

"Scientific Libraries in the Emergency." College and Research Libraries $1: 328-29,398$, September 1940 .

"Teaching with Books by Harvie Branscomb." Bulletin of the American Association of University Professors 26:262-65, April 1940.

"Use of Books in Specific Courses of Instruction." A.L.A. Bulletin 34:446-47, Sept. I, 1940.

I94I "Educational Isolationism and the $\mathrm{Li}$ brary." A.L.A. Bulletin 35:405-09, July 1941. Also appeared in Library Journal $66: 586-88$, July 1941.

"Four Immediate Objectives." School Life 27:11, October 194I.

"Future Goals of the College Library." In "Henry Pfeiffer Library, MacMurray College for Women." Bulletin of MacMurray College for Women (series I), v. 3I, no. 7 , I94I, 24p. Address at the dedication of the library.

"Incomplete Files of Current Periodicals in American Libraries." Science (new series) $93: 496$, May 23, I941.

"Librarians and the War." College and Research Libraries 3:99-100, 116, March 1942. Appeared also under title "Education for Freedom and Permanent Security," in Library Journal 67:55-56, Jan. 15, 1942; South Dakota Library Bulletin 28:29-30, April 1942.
"Librarians Interested in National Defense." Library Journal 66:1026, Dec. I, 1941.

"Message from President Brown." A.L.A. Bulletin 35:694-95, December 1941. Also appeared in Wilson Library Bulletin 16:34849, January 1942.

"Open Letter." Wilson Library Bulletin 16:12-13, September 1941.

Portrait. A.L.A. Bulletin 35:468, Oct. I, 1941 ; Library Journal 66:604, July 1941.

"Significance of the Hoover Library on War, Revolution, and Peace." In Dedication of the Hoover Library on War, Revolution and Peace, Stanford University, June 20, I94I. Stanford University, Calif., Stanford University Press, I94I, p. 2-5.

1942 "American Association of Law Libraries and the American Library Association." Law Library Journal 35:400-02, September 1942.

"Contribution of Books to a New World." A.L.A. Bulletin 36:456-59, July 1942. Also appeared in Library Journal 67:597-99, July 1942.

"Education for Freedom and Permanent Security." Library Journal 67:55-56, Jan. 15, 1942. Also appeared in South Dakota Library Bulletin 28:29-30, April 1942; and College and Research Libraries 3:99-100, March 1942 (with title: "Librarians and the War").

"First Things First; Librarians' Wartime Opportunity and Paramount Duty." Library Journal 67:931-33, Nov. I, 1942. Also appeared in Iowa Library Quarterly 14:118-20, October-December 1942; and South Dakota Library Bulletin 29:3-6, January 1943.

"For United Action." A.L.A. Bulletin 36:I I, January 1942. Also appeared in South Dakota Library Bulletin 28:5, January 1942.

"Interest of the American Library Association in the Joint University Libraries." In Development of University Centers in the South. Ed. A. F. Kuhlman. Nashville, Tenn., Peabody Press, .1942, p. 108-10. Also appeared in Peabody Reflector 15:29, January 1942.

"Let's Get on with the War!" A.L.A. Bulletin 36: inside front and back covers, November 1942. Also appeared in About Books (Wesleyan University Library) I3:I, September-December 1942.

"Report of the President [of the American Library Association]." A.L.A. Bulletin 36: 
647-50, Oct. 15, 1942.

"Unity among Library Organizations." Special Libraries 33:213-15, July-August 1942.

War Services of the Iowa State College Library Available to All Citizens of the State of Iowa. Ames, Iowa State College Library, January 1942, 6p.

"War Services Offered by the Iowa State College Library." A.L.A. Bulletin 36:66-68, February 1942.

1943 "College Libraries and the War." Libraries and the $W$ ar, no. $8,6 \mathrm{p} . ;$ no. 12 , 8p.; and no. 14, 7p. Chicago, American Library Association, 1943.

"College Libraries and the War." Library Journal 68:333, Apr. 15, 1943; 47 1, June I, 1943.

"Facts and Their Interpretation; Use Your Library." Illinois Libraries 25:386-88, December 1943.

"Library Cooperation with the Orient and. South Pacific." A.L.A. Bulletin 37:327-28, Oct. 15, 1943.

J"Our Stake in China." A.L.A. Bulletin 37:447-5 I, Dec. I, 1943.

Portrait. A.L.A. Bulletin 37:2, January 1943.

1944 "A.C.R.L. Notes: Material for Exhibits on China;" "Postwar Planning for College Libraries." Library Journal 69:110, Feb. I, 1944.

"Allotments for Library Service to Army and Navy Units." Library Journal 69:314, Apr. 15, 1944.

"China News: A Request from China; SinoAmerican Cooperating Committees." Library Journal 69:69I, Sept. I, 1944.

"Co-operative Purchasing in China." $\mathrm{Li}$ brary Journal 69:27-28, Jan. I, 1944.

"The Emerging Program of Cultural Relations" by Charles A. Thomson. Discussion by Charles H. Brown. A.L.A. Bulletin 38 : 79-8o, February 1944.

"Implementation of the China Program." Library Journal 69:238-41, Mar. 15, 1944.

$A$ Program for the Development of the Library of Tuskegee Institute in Support of the Expansion of the Instructional Program. Ames, Iowa State College Library, 1944. 19 numb. leaves. (Mimeographed.)

1945 "An Appreciation of Laura Woodward." Special Libraries 36:17, January
1945.

"China and the Far East." A.L.A. Bulletin 39:356-57, Oct. 15, 1945.

"Harold L. Leupp, Administrator." College and Research Libraries 6:353-54, September 1945 .

"Libraries and Graduate Programs, Especially in the Scientific Fields." College and Research Libraries 6:101-05, March 1945.

The Library in Graduate Instruction. Tuskegee Institute, Ala., Tuskegee Institute, 1945. 6p. Paper read at the Conference of Presidents of Negro Land-grant Colleges, Chicago, Oct. 24, 1944.

"Union Catalogs and Problems of Collecting." College and Research Libraries 6:415I7, September 1945.

1946 "The A.C.R.L. and the A.L.A." $\mathrm{Li}$ brary Journal 71:1005-10, August 1946.

"College Library Objectives and Their Attainment." In College and University $\mathrm{Li}$ braries and Librarianship. Prepared by the College and University Postwar Planning Committee of the American Library Association and the Association of College and Reference Libraries, William Hugh Carlson, chairman. Chicago, American Library Association, 1946, p. 9-15.

"General Statements." In "The Place of College and Reference Library Service at A.L.A. Headquarters: A Symposium." College and Research Libraries 7:161-63, April 1946.

"[Robert W. Orr]." College and Research Libraries 7:350-51, October 1946.

1947 "What Do the Members of A.C.R.L. Want?" College and Research Libraries 8: 3-10, 43, January 1947.

\section{Biographical Sketches}

Mr. Brown has been the subject of the following editorials and biographical articles:

Spaulding, Forrest. "Charles Harvey Brown." Bulletin of Bibliography 16:21-22, January-April 1937.

Current Biography, 1941. New York City, H. W. Wilson Co., 1941, p. I12-13.

Library Journal $47: 972$, Nov. 15, 1922; $71: 988$, July 1946.

Who's Who in America. Chicago, A. N. Marquis Co., 1944, p. 149.

Who's Who in Library Service. New York City, H. W. Wilson Co., 1933, p. 91. 